\title{
Diziplina Anitzeko PBL-a Ingeniaritzan: esperientzia bat Software Ingeniaritza eta Datu-baseak Irakasgaietan
}

(Multidisciplinary PBL in Engineering: an Experience in the Subjects Software Engineering and Databases)

\author{
Anaje Armendariz*, Maider Azanza, Idoia Berges
}

Lengoaia eta Sistema Informatikoak saila, Euskal Herriko Unibertsitatea (UPV/EHU)

LABURPENA: Azken urteetan aldaketa asko izan dira hezkuntza arloko maila guztietan, haur hezkuntzatik hasi eta unibertsitateraino. Unibertsitatean ohikoa zen 200 ikasleko eskolak egokitzea, batez ere teoriaren irakaskuntzari zuzenduta zeudenak. Gaur egun, ordea, ikasle kopurua askoz ere txikiagoa da eta eskolak askoz ere praktikoagoak. Honek aukera ematen du metodologia ezberdinak aplikatu ahal izateko, Project Based Learning $(P B L)$ izenekoa adibidez, non ikasleek edukiak proiektu baten garapenaren bitartez barneratzen dituzten. Metodologia hori aplikatuz 2017/2018 ikasturtean diziplina anitzeko proba pilotu bat egin zen Bilboko Ingeniaritza Eskolako Kudeaketaren eta Informazio Sistemen Informatikaren Ingeniaritzako graduko Software Ingeniaritza eta Datu-baseak irakasgaien artean, proiektu amankomun bat zehazki. Artikulu honetan azaltzen da esperientzia zein izan zen eta zer ondorio atera ziren handik.

HITZ GAKOAK: Unibertsitate hezkuntza, PBL, Software Ingeniaritza, Datu-baseak.

ABSTRACT: In recent years there have been many changes at all levels of education, from preschool to university. It was common at university to have classes of 200 students, mostly aimed at teaching theory. Nowadays, however, the number of students is much smaller and the classes much more practical. This allows different methodologies to be applied, such as Project Based Learning $(P B L)$, where students internalize contents through the development of a project. Applying this methodology, a multidisciplinary pilot test was carried out in the 2017/2018 academic year in the BSc in Computer Management and Information Systems Engineering of the Faculty of Engineering in Bilbao between the courses of Software Engineering and Databases, specifically a common project. This article explains what the experience was like and what conclusions were drawn from it.

KEYWORDS: University education, PBL, Software Engineering, Databases.

\footnotetext{
* Harremanetan jartzeko / Corresponding author: Anaje Armendariz. Lengoaia eta Sistema Informatikoak Saila, Bilboko Ingeniaritza Eskola, Euskal Herriko Unibertsitatea (UPV/EHU), Rafael Moreno «Pitxitxi», 3 (Bilbo, Bizkaia). - anaje.armendariz@ ehu.eus - https://orcid.org/0000-0002-3232-5294.

Nola aipatu / How to cite: Armendariz, Anaje; Azanza, Maider; Berges, Idoia (2021). «Diziplina Anitzeko PBL-a Ingeniaritzan: esperientzia bat Software Ingeniaritza eta Datu-baseak Irakasgaietan»; Ekaia, 39, 2021, 337-353. (https://doi.org/10.1387/ekaia.21866).

Jasoa: 2020, ekainak 29; Onartua: 2020, abuztuak 29.
}

ISSN 0214-9001 - elSSN 2444-3255 / (C) 2021 UPV/EHU

(i) (i) Obra hau Creative Commons Atribución 4.0 Internacional-en lizentziapean dago 


\section{SARRERA}

Urteak pasa ahala, hezkuntza aldatuz doa maila guztietan. Gaur egungo umeek jasotzen dituzten eskolek ez dute zer ikusirik orain dela 30 urte jasotzen zirenekin. Gauza bera gertatzen da unibertsitate-mailan ere. Garai batean gelak handiak ziren, askotan 200 ikaskide zeuden gela berean, irakaslea gelara sartu, gaia azaldu eta joan egiten zen. Eskolak guztiz teorikoak ziren, eta irakasleak ez zuen harreman askorik izaten ikasleekin. Baina egoera asko aldatu da: gaur egun gelak txikiagoak dira, ikasle gutxiago daude bertan, irakasleak bere ikasleak ezagutzen ditu eta eskolak askoz ere praktikoagoak izaten dira, noski, teoria azaldu behar dela inoiz ahaztu gabe.

Praktikotasun-behar honetan oinarrituz, azken urteetan indar handia hartu du Project Based Learning (PBL) delakoak, hots, proiektuetan oinarritutako ikaskuntzak. Metodologia honek ikaslea jartzen du ikasketaren ardaztzat, horrela, ikasleek modu koordinatu batean lan egiten dute eta proiektua garatzen duten bitartean ikasiz joaten dira. Abantaila asko erakutsi ditu ikasteko modu honek, akademikoki emaitza hobeak lortzea eta lan mundu profesionalerako prestatzen laguntzea barne. Hala ere, metodologia honen aplikazioak hausnarketa bat eskatzen du irakasleen aldetik. Unibertsitateko irakaskuntzaren antolaketa tradizionalean irakasgaiak eremu isolatuak dira, bakoitzaren barruan ikasleak bere irakasgaiko kontzeptuak lantzen dituelarik. Baina lan-mundua ez da horrelakoa izaten, eta sarritan arazo baten aurrean irakasgai desberdinekin lotutako kontzeptuak aplikatu behar dira.

Artikulu honetan 2017/2018 ikasturtean Bilboko Ingeniaritza Eskolako Kudeaketaren eta Informazio Sistemen Ingeniaritzako graduan irakasgaien arteko mugak gainditzeko egindako proba pilotua azaltzen da. Bertan, Software Ingeniaritza eta Datu-baseak irakasgaietan landu beharreko proiektuak batu ziren, horrela ikasleek softwarearen garapen-prozesu osoaren ikuspegi orokorra lortzen zuten. Koordinaketa estua eskatu zuen arren, esperientzia oso aberasgarria izan zen bai irakasleentzat eta baita ikasleentzat ere.

Artikuluaren egitura honako hau da: lehenik eta behin proiektuen garrantzia hezkuntzan azaltzen da (2. atala), ondoren gure proiektuan parte hartzen duten bi irakasgaiak deskribatzen dira graduko testuinguruan (3. atala). Ondoren, planteatutako proiektua azaltzen da (4. atala), eta handik aterako emaitzak laburtzen dira (5. atala), eta ikasitako lezio (6. atala) eta ondorioekin bukatzen da (7. atala).

\section{PROIEKTUEN GARRANTZIA HEZKUNTZAN}

Urteetan zehar praktikak eta proiektuak ohikoak izan dira hainbat irakasgaitan, irakasten zena ikasleriak ondo ikasi eta praktikan jar zezan. 
Urteak pasa ahala PBL [1] [2] deituriko metodologia garatu eta indarra hartzen joan da. Metodologia honek ikaslea jartzen du ikasketaren ardatz moduan, horrela, ikasleek modu koordinatu batean lan egiten dute eta proiektua garatzen duten bitartean ikasiz joaten dira. Zehazki, PBL proiektu batek honako ezaugarri hauek ditu:

- Lan-mundurako profesionalki prestatzen laguntzen du.

- Erakargarriagoa da, bai irakasleentzat eta baita ikasleentzat ere.

- Akademikoki emaitza hobeak lortzen dira eta uzte-tasa jaisten da.

- Arazoa gelan azaltzeak teoria irakatsi aurretik ikasleak motibatu egiten ditu.

- Erabilerak eta parte-hartzeak ikasitakoa gogoan gordetzen laguntzen du.

PBL metodologia egunetik egunera gehiago erabiltzen da hezkuntzaren maila guztietan, lehen hezkuntzatik [3] unibertsitatera [4]. Eusko Jaurlaritzak diseinatutako Heziberri 2020 planak ere bultzatu nahi ditu ezagutza anitzeko PBL esperientziak [5]. Lehen hezkuntzan esperientzia ugari egiten ari dira, kasu askotan proiektu bakar batean hainbat ezagutza landuz. Adibidez, 2015. urtean, IV encuentro de buenas prácticas en la educación deituriko kongresuko aurkezpen batean, lehen hezkuntzako ikasleek merkatu baten bidez matematikak, hizkuntza, plastika edo gizartea gaiak nola landu zituzten azaldu zuten [6]. Bigarren hezkuntzan eta heziketa zikloetan ere egin dira horrelako esperientziak, adibidez, Errenteriako Don Bosco heziketa zentroan ${ }^{1}$, Goi mailako Mekatronika Industriala, esate baterako, PBL metodologia erabiliz irakasten da.

Bestalde, unibertsitatean ere hainbat esperientzia egin dira azken urteetan, arlo oso ezberdinetan, hala nola magisteritzan edo ingeniaritzetan. Adibidez [7]n ageri den moduan, Sevillako Unibertsitatearen Lehen Hezkuntzako graduan bigarren mailako ikasleekin lan egin zen, PBL metodologiari jarraituz edukiak, talde lana edo aurkezpenak landu zirelarik. Kasu batzuetan PBL metodologia diziplina anitzak batuz aplikatu izan da. Esate baterako, 2004/2005 ikasturtean Zaragozako Unibertsitatean, Kudeaketa Informatikan Ingeniaritza Teknikoan esperientzia berri bat aurrera eramatea erabaki zuten [8]. Han hiru irakasgai (Estrategiak eta Informazio Sistemak, Merkataritza Elektronikoa eta Erabiltzailearen Interfazeak) elkartu eta proiektu amankomun bat garatu zuten ikasleek, emaitza bikainekin. Azkenik, aipatzekoa da Alikanteko Unibertsitateko Multimedia Ingeniaritzako Graduan egindako esperientzia. Han, 4. mailan zazpi irakasgai elkartu zituzten proiektu amankomun batean [9].

Irakasgai bakoitzeko edukietaz gain, aipatu beharra dago PBL gaitasun transbertsalak lantzeko ere erabili dela, hau da, antolaketa eta plangin-

1 https://donbosco.hezkuntza.net/eu 
tza kapazitatea, talde lana edo analisi kritikoa bezalako gaitasunak. Honen inguruan [10]n Ingeniaritza Informatikoko ikasleen ikuspuntua aztertu zuten eta ikasleek konpetentzia hauek lortzeko PBL metodologiak balio izan zuela adierazi zuten. Aurrekoan oinarrituz, 2017/2018 ikasturtean Bilboko Ingeniaritza Eskolako Kudeaketaren eta Informazio Sistemen Informatikaren Ingeniaritzako graduan esperientzia pilotu bat egin genuen, PBL aplikatuz diziplina anitzeko proiektu bat planteatuz Software Ingeniaritza eta Datu-baseak irakasgaien artean. Proiektu horri esker software garapen eta datu-kudeaketaren arloen arteko loturak argi erakusten dira, Ingeniaritza Informatikoko graduatu batek lan munduan ezinbestekoa izango duen ikuspegi orokorrera hurbilduz.

\section{IRAKASGAI ETA PROIEKTUAREN KOKAPENA GRADUAN}

Kudeaketaren eta Informazio Sistemen Informatikaren Ingeniaritzako Gradua ikasi ondoren, ikaslea gai izango da erakundeen beharretara egokitutako soluzio informatikoak sortzeko edozein fasetan, hau da, diseinatzeko, garatzeko eta hedatzeko, baina baita proiektuak zehaztu, planifikatu, zuzendu eta kudeatzeko ere. Gradu honek guztira 240 kreditu dauzka, lau ikasturtetan banaturik. Bigarren mailako bigarren lauhilekoan daude kokatuta Datu-baseak eta Software Ingeniaritza irakasgaiak, 1. irudian ikusten den bezala.

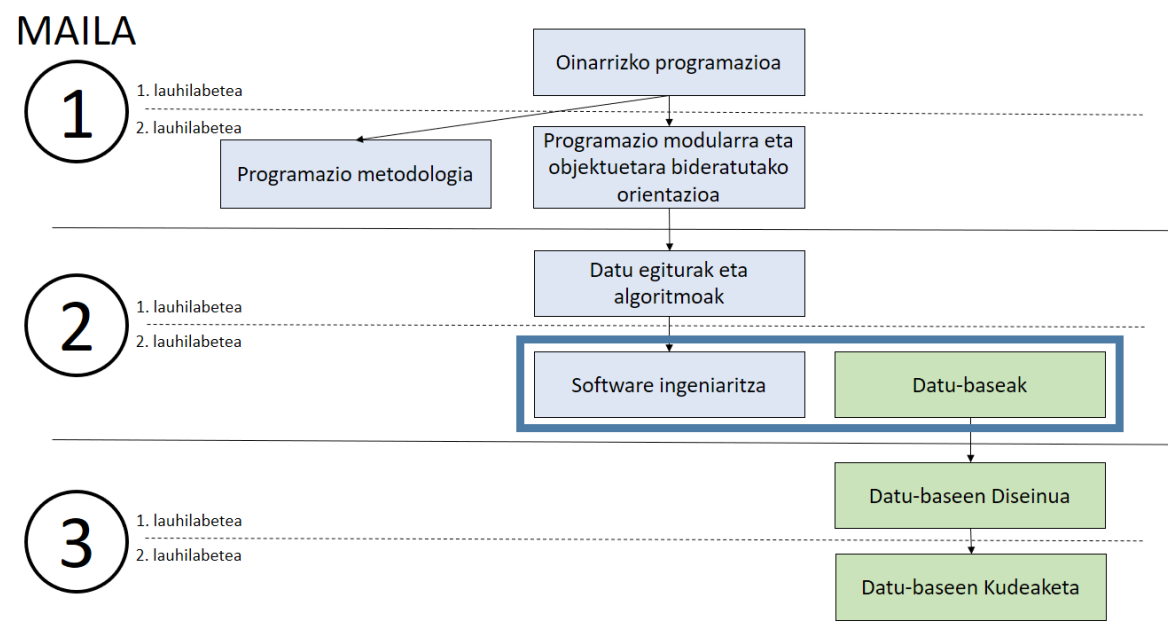

1. irudia. Softwarearen garapenaren eta datu-kudeaketaren arloko irakasgaiak (urdinez eta berdez, hurrenez hurren).

Datu-baseak irakasgaian datu-baseen diseinua eta inplementazioa ondo ulertzeko beharrezkoak diren kontzeptuak azaltzen dira. Adibidez, datu-ba- 
seen ezaugarriak, funtzionaltasunak eta egitura aztertzen dira, eta hauek aplikazioen garapenean erabiltzen ikasten da. Graduan datu-baseekin lotutako lehenengo irakasgaia da; beraz, gaia hutsetik hasten da. Honen ondorioz ikasleek normalean bigarren urtean hartzen dute irakasgaia, zer duten gaindituta edo gainditu gabe kontuan hartu gabe.

Irakasgai honek sei kreditu ditu, hiru kreditu magistral eta beste hiru ordenagailu praktiketan. Eskola magistraletan teoria azaltzen da eta ariketak egiten dira: datu-baseen oinarriak, datu-baseen diseinuaren oinarriak, SQL lengoaia eta transakzioak. Zati praktikoan, berriz, eskola magistralean ikusitako teoria praktikara eramaten da eta aplikazio batetik datu-base baten datuetara atzipenean sakontzen da.

Azken urteotan ikasleek irakasgaian proiektu bat egin behar izan dute. Lau edo bost ikasleko taldetan banatzen dira, eta gai bat banatzen zaie, adibidez motorrak konpontzeko tailer bat. Gai horren inguruan datu-base bat diseinatu, eta datu-base hori erabiliz hainbat funtzionalitate eskaintzen dituen aplikazio bat egin behar izaten dute transakzioak eta SQL sententziak landu ahal izateko, irakasgaiko irakasleen aurrean aurkezpen bat eginez amaituz. Esan beharra dago saiatzen garela garatu beharreko aplikazioa sinplea izaten diseinu eta inplementazio aldetik, esfortzua batez ere irakasgaiaren edukietan (datu-basearen inguruan) egiteko.

Software Ingeniaritza irakasgaiaren helburu orokorra aplikazioak diseinatu eta inplementatzen ikastea da, aurretik horien betekizunak zeintzuk diren ezagututa. Software-prozesu sistematiko baten bidez garatzeko metodologia arinak eta maila anitzeko software arkitekturak erabiltzen dira, software kalitatea bermatzen laguntzen duten erremintak erabiliz. Irakasgai honek sei kreditu ditu, hiru kreditu magistral eta beste hiru ordenagailu praktiketan, eta softwarearen garapenari lotuta dauden graduko beste irakasgai batzuen ondoren dator, Oinarrizko Programazioa, Programazio Modularra eta Objetuetara Bideratutako Orientazioa eta Datu Egiturak eta Algoritmoak, esate baterako. Beraz, ikasleek irakasgai horien edukian barneratuta dituztela jotzen da. Horren ondorioz, aurreko irakasgaiak gaindituta ez dituzten ikasleek ez dute irakasgaia hartzen; beraz, ohikoa da ikasle batzuk bigarren urtean irakasgai honetan ez matrikulatzea.

Horrela, eskola magistraletan teoria azaltzen da, software ingeniaritzaren sarrera, UML artefaktuen espezifikazioak, maila ezberdinetako software ariketak, objektuetara bideratutako diseinu eta programazioa edo produktu jakin baten inplementazioa, esate baterako. Eskola magistraletan ikasitako guztia praktikara eramateko asmoarekin, ikasleek proiektu bat garatzen dute taldeka. Bertan bezero bat izaten dute (irakasleak), betekizunak ematen dizkiena. Orokorrean datu-atzipen sinple bat behar duten aplikazioak izaten dira, Flota Urperatu edo Sudokua esaterako. Sistema diseinatu, inplementatu eta probak egin ondoren bezeroari emaitza aurkezten 
dio talde bakoitzak. Ikus daiteke bi irakasgaietan proiektu bat garatu behar izaten dutela ikasleek aldi berean, bata esfortzua informazioaren kudeaketan jartzen duena, aplikazioaren diseinu eta inplementazio sinple batekin, eta bestea esfortzua aplikazioaren diseinu eta inplementazioan jartzen duena, datu atzipen sinplearekin, amaieran bien aurkezpena eginez. Gainera, proiektu bakoitza gai bati buruzkoa da, dokumentazio aldetik betebehar ezberdinak ditu eta askotan ikaskide ezberdinekin garatu behar dute, honek dakartzan oztopoekin, adibidez bilerak koordinatzeko.

Hau dela eta, zentzuzkoa iruditu zitzaigun proiektu amankomun bat eskatzea, diseinu, inplementazio eta informazioaren kudeaketaren aldetik aberatsa dena, dokumentazio amankomunarekin eta aurkezpen bakarrarekin. Izan ere, Informatika Ingeniaritzaren kasuan, proiektu baten garapenean funtzionalitatearen diseinua (Software Ingeniaritza) eta beharrezkoak diren datuen kudeaketa (Datu-baseak) era koordinatu batean eraman behar dira hasieratik. Hortaz, garrantzitsua da ikasleek ezagutza-eremu ezberdinen loturak ikustea eta proiektua diziplina anitzeko ikuspegi batetik lantzea, hori baita eremu profesionalean aurkituko duten egoera.

\section{PROIEKTU AMANKOMUNA: ANIMALIEN TABERNA}

Proiektu honek bi fase izan zituen, proiektuaren prestaketa eta proiektuaren gauzatzea. Lehen zatian proiektua nola pentsatu eta nola diseinatu genuen azaltzen da; bigarrenean, berriz, ikasleekin aurrera nola eraman zen.

\subsection{Proiektuaren Prestaketa}

Lehenengo pausoa proiektuarentzat gai egoki bat aurkitzea izan zen, bi irakasgaien helburu pedagogikoak betetzeaz gain, ikasleen interesa piztuko lukeena.

Software Ingeniaritza irakasgaiari dagokionez, honako hauek bete behar zituen aukeratutako gaiak: (i) diseinu erabakien garrantzia erakustea, (ii) gutxienez hiru edo lau diseinu-patroiren erabilera, (iii) garapen iteratiboa bermatzea, (iv) hiru mailatako arkitekturaren garrantzia erakustea, (v) interfaze grafiko ez-tribialak izatea eta (vi) datu-atzipena izatea.

Halaber, Datu-baseak irakasgaiaren aldetik honako hauek ziren gaiak bete beharrekoak: (i) datu-base baten beharra izatea informazioa gordetzeko (ii) datu-base bat diseinatu eta inplementatzea, (iii) aplikazio batetik datu-basean informazioa sartu, eguneratu eta ezabatzea, (iv) aplikazio batetik datu-basearen informazioa atzitzea eta (v) transakzioak erabiltzea.

Software Ingeniaritza irakasgaian historikoki jokoak simulatzen dituzten aplikazioak garatu izan dira, lehen aipatutako Flota Urperatu edo Su- 
dokua, esate baterako. Esperientziak dio jokoak ikasleentzat erakargarriak direla eta proiektuan lan egiteko motibatu egin ohi dituztela. Gainera, interfaze grafikoak garatzeko aukera interesgarriak eskaintzen dituzte. Ildo beretik jarraituz, Animalien Taberna jokoa ${ }^{2}$ garatzea erabaki zen $2017 \mathrm{ko}$ uztailean. Jokoaren dinamika nahiko sinplea da: jokalari bakoitzak animaliak dituen karta sorta bat jasoko du. Txandaka animaliak taberna batera sartzeko ilaran jarriko dira, eta animalia bakoitzak dituen ezaugarriak kontuan hartuz, ilaran posizio onena lortzen saiatu behar du. Noizean behin tabernaren ateak irekiko dira eta ilarako lehenak sartuko dira. Irabazlea amaieran jokalari bakoitzak taberna barruan dituen animalien arabera kalkulatzen da.

Animalia bakoitzak bere portaera duenez, aplikazioak diseinu aldetik erronka bat dakar eta bisualki erakargarria da. Datu-baseak irakasgaiari dagokion datu iraunkortasunari begira, jokoari saioa hasteko funtzionalitatea gehitzea erabaki zen, jokalariak behin kautotuta bakarrik joka zezakeelarik, eta baita honekin lotuta dagoen jokalariak kudeatzeko (erregistratu, aldatu, ezabatu) funtzionalitatea ere. Gainera, behin partida amaituta, partidako puntuak gorde eta erabiltzaileari ranking ezberdinak erakutsiko zitzaizkion, bere burua beste jokalariekin konparatu ahal izateko. Honetaz gain, jokoa pertsonalizatzeko aukera eman behar zen animalia berriak gehituz, eta azkenik, amaitu gabeko partida bat gordetzeko beharrezkoa zen datu-basearen diseinua egitea eskatu zen.

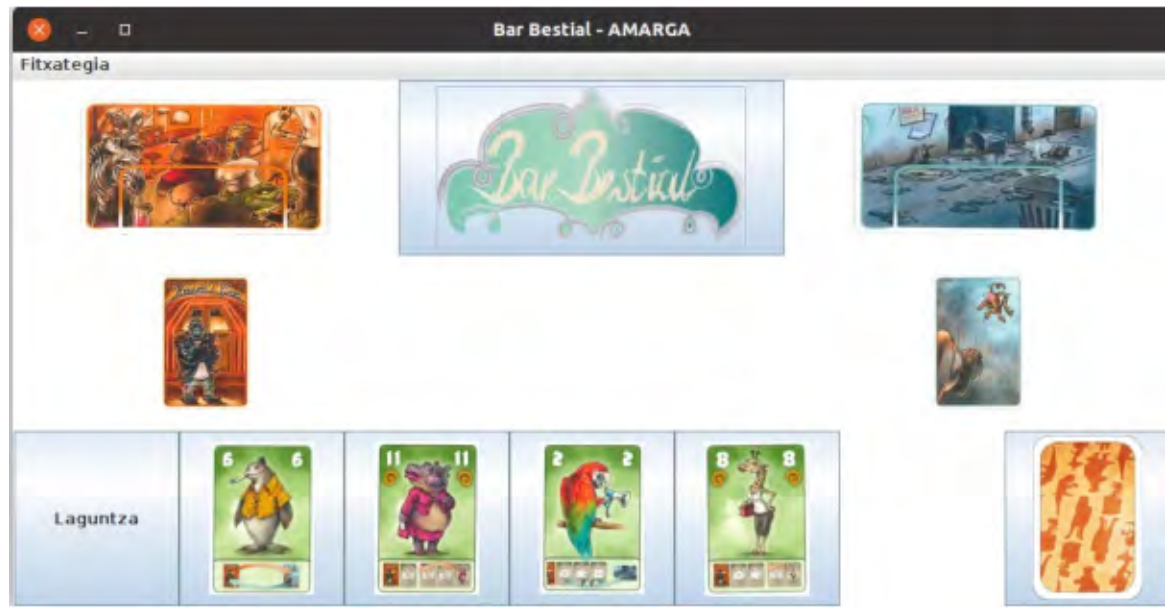

2. irudia. Sortutako aplikazioen adibidea, AMARGA taldeak eginda.

2 http://devir.es/producto/bar-bestial/ 
Bigarren pausoa bi irakasgaien plangintzak eta proiektua koordinatzea izan zen. Honetarako pisu gehien duen proiektuan, Software Ingeniaritza irakasgaikoan, oinarritu ginen. Proiektua lauhilabeteko hirugarren astean aurkeztu ohi da, lana laugarren astean hasten delarik. Proiektuaren garapena hiru edo lau astetako hiru iteraziotan egiten da, iterazio bakoitzean funtzionalitate multzo bat garatzen delarik. Iterazio bakoitzaren amaieran bezeroarekin, hots, irakaslearekin, bilera bat egiten da eta haren feedback-a jasotzen da. Azken iterazioarekin batera bezeroari garatutako produktuaren aurkezpena egiten zaio.

Hau horrela izanda, lehengo bi iterazioetan datu-baseekin zerikusirik ez zuten funtzionalitateak kokatu ziren, jokoaren hasieraketa eta erabiltzaileak kartak jokatzea ahalbidetzen zutenak. Datu-baseekin lotura zuten funtzionalitateak azken iteraziorako utzi ziren. Bigarren pauso hau 2017ko iraila eta abendua bitartean egin zen.

\subsection{Proiektuaren Gauzatzea}

Proiektua, proba pilotu modura, euskarako taldean bakarrik aurrera eramatea erabaki zen. Arrazoiak bi izan ziren: (i) ikasle kopurua txikiagoa zen (gaztelaniako taldean 73 ikasle zeuden Software Ingeniaritza irakasgaian) eta (ii) irakasgaien arteko solapamendua handiagoa zen, hots, ikasle gehienek bi irakasgaiak zituzten.

Zehazki, euskarako taldean bi irakasgaien artean guztira 43 ikasle ezberdin zeuden matrikulatuta, horietako 28 bi irakasgaietan. Bederatzi ikasle Software Ingeniaritza irakasgaian bakarrik zeuden, denek aurretik Datu-baseak irakasgaia gaindituta zutelarik. Sei ikasle bakarrik Datu-baseak irakasgaian matrikulatuta zeuden eta ez zuten aurretik Software Ingeniaritza irakasgaia egin. Datu hauek aurreko ikasturtetakoekin bat zetozen, Software Ingeniaritza bigarren mailan azkena gainditu ohi den irakasgaia baita.

Hau horrela, Software Ingeniaritza bakarrik zuten ikasleentzat ez zen proiektua egokitu behar izan, aurrera ateratzeko gai ziren bere garaian ikasitakoa aplikatuz eta bi irakasgaien arteko lotura ikusteko erabilgarria zitzaien, bi irakasgaiak batera jorratzen ari ziren ikasleei bezala. Bakarrik Datu-baseak irakasgaian matrikulatutako sei ikasleei, aldiz, proiektuaren moldaketa bat prestatu zitzaien, non bakarrik Datu-baseak irakasgaiaren edukiak landu behar zituzten.

Proiektua lauhilabetearen hirugarren astean aurkeztu zen eta ikasleak laugarren astean hasi ziren lanean. Aplikazioaren garapenaren kontrola Software Ingeniaritza irakasgaian eraman zen, Datu-baseak irakasgaiari lotutako edukiak hirugarren iterazioan sartu zirelarik (hamaikagarren astean) lehen aipatu den modura. Bizitza errealeko proiektuen amaierak simulatuz, hamabostgarren astean bezeroari garatutako proiektuaren aurkezpen publi- 
koa egin zitzaion, non irakasgaietako hiru irakasleok bezero papera hartu genuen. 2. irudian ikus daiteke ikasleek garatutako aplikazio baten adibidea.

Euskara

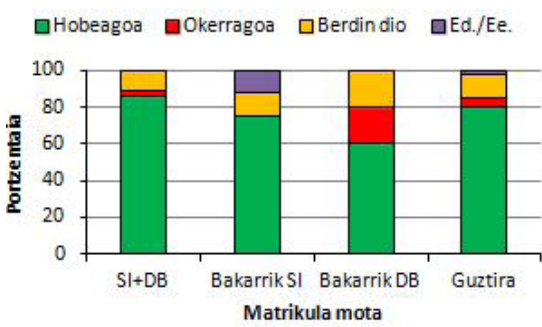

Gaztelania

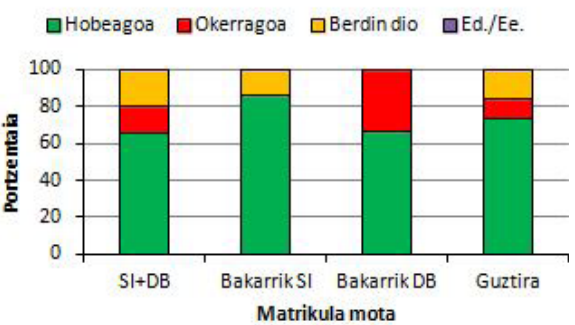

Euskara eta gaztelania

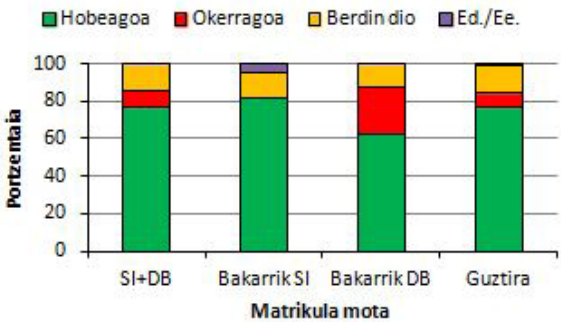

3. irudia. Zure iritziz, bi irakasgaietan matrikulatuta dauden ikasleentzat aurten erabilitako formula (proiektu bakarra) aurreko urteetan erabilitakoa (bi proiektu ezberdin) baino hobea da? galderaren emaitzak talde bakoitzean eta bi taldeak kontuan izanda. SI+DB, Bakarrik SI eta Bakarrik DB zutabeek bi irakasgaietan, Software Ingeniaritza irakasgaian bakarrik eta Datu-baseak irakasgaian bakarrik matrikulatutako ikasleen emaitzak jasotzen dituzte, hurrenez hurren. Guztira zutabeak ikasle guztien emaitzak jasotzen ditu.

Nahiz eta proiektuaren kudeaketak irakasleen arteko koordinazio-lan estua eskatu, batez ere lehen urtea izanda, esan beharra dago irakasleok oso pozik gelditu ginela esperientziarekin, bai emaitza aldetik eta baita ikasleen inplikazio aldetik ere. Hurrengo atalak ikasleen emaitzak eta iritziak laburtzen ditu.

\section{EMAITZAK ETA IKASLEEN IRITZIAK}

Behin irakasgaiak amaituta, inkesta bat pasa genien bai euskarako taldeko ikasleei (hau da, esperientzia berrian parte hartu zutenak) eta baita gaztelaniako taldeko ikasleei ere (hau da, irakasgaiak ohiko moduan landu 
zituztenak, irakasgai bakoitzean proiektu ezberdin bat eginez). Horretarako, aldez aurretik, gaztelaniako ikasleei euskarako taldean egindako esperientzia zein izan zen azaldu zitzaien. Interesgarria iruditu zitzaigun inkesta bi taldeetan egitea, esperientziaren emaitza errealak (euskarako taldea) eta ikasleek aurreikusitakoak (gaztelaniako taldea) alderatu ahal izateko.

Euskarako taldean 41 ikaslek erantzun zioten inkestari. Horietako 28 bi irakasgaietan matrikulatuta zeuden, zortzi Software Ingeniaritza irakasgaian bakarrik, eta bost Datu-baseak irakasgaian bakarrik. Gaztelaniako taldean, berriz, 37 ikasleren erantzunak jaso genituen. Horietako 20 bi irakasgaietan matrikulatuta zeuden, 14 Software Ingeniaritza irakasgaian bakarrik, eta hiru Datu-baseak irakasgaian bakarrik.
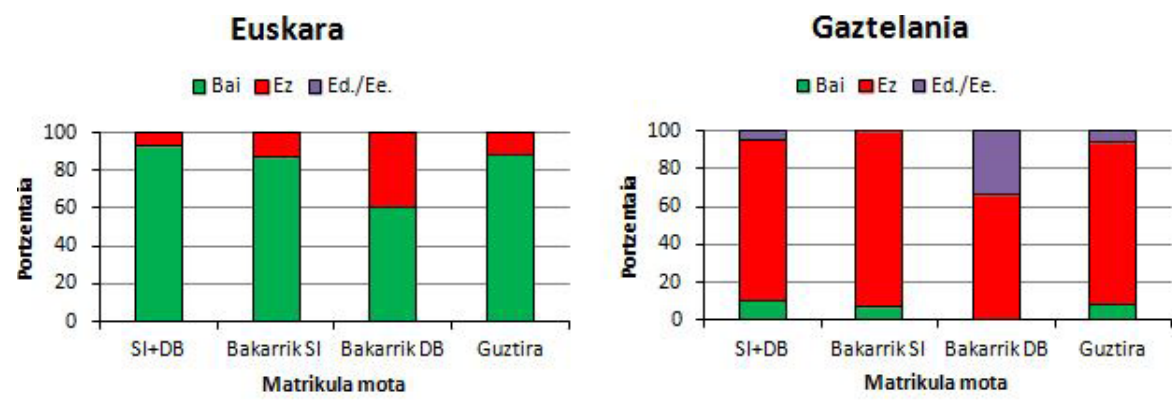

\section{Euskara eta gaztelania}

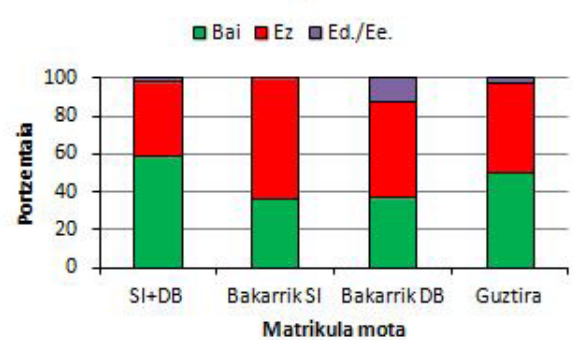

4. irudia. Gomendatuko zenioke etorkizuneko ikasle bati bi irakasgaietan ikasturte berean matrikulatzea proiektu amankomuna egiteko, horretarako (beharrezkoa balitz) itxaron beharko balu ere? galderaren emaitzak talde bakoitzean eta bi taldeak kontuan izanda.

Ondoren, jasotako emaitza batzuk aurkeztuko ditugu. Galdera bakoitzean, erantzunaz gain, ikasleei erantzuna arrazoitzeko aukera eman zitzaien. 3. irudian «Zure iritziz, bi irakasgaietan matrikulatuta dauden ikasleentzat aurten erabilitako formula (proiektu bakarra) aurreko urteetan erabilitakoa (bi proiektu ezberdin) baino hobea da?» galderaren erantzunak aurkitu daitezke. 
Ikus daiteke ikasle gehienek (\% 76,9), bai euskarako taldean $(\% 80,5)$ bai gaztelaniako taldean $(\% 73,0)$, eta edozertan matrikulatuta zeudela, formula berria aurreko urteetakoa baino hobea zela ziotela. Bi arrazoi nagusi aipatzen zituzten formula berriaren alde: alde batetik, proiektu amankomunak bi irakasgaien arteko erlazioa argiago ikustea ahalbidetzen duela, eta bestalde, etorkizunean lanean aurkituko duten egoera hobeto islatzen duela. Formula berriaren kontra zeuden ikasleek, berriz, proiektu amankomun bat irakasgaietako bat alde batera uzteko erabakia hartzen duten ikasleentzat kaltegarria izango zela aipatzen zuten, beste irakasgaian eragina izango zuelako.

4. irudian «Gomendatuko zenioke etorkizuneko ikasle bati bi irakasgaietan ikasturte berean matrikulatzea proiektu amankomuna egiteko, horretarako (beharrezkoa balitz) itxaron beharko balu ere?» galderaren erantzunak ikus daitezke. Euskarako taldean emaitzek argi erakusten dute ikasleek bi irakasgaietan aldi berean matrikulatzea gomendatzen dutela, horretarako itxarotea beharrezkoa bada ere $(\%$ 87,8). Esan beharra dago orokorrean ikasleak bi irakasgaietan ikasturte berean matrikulatu beharko liratekeela biak bigarren mailakoak direlako. Hala ere, kasu batzuetan ikasleak batean bakarrik matrikulatzen dira bestea etorkizunerako utziz ${ }^{3}$.
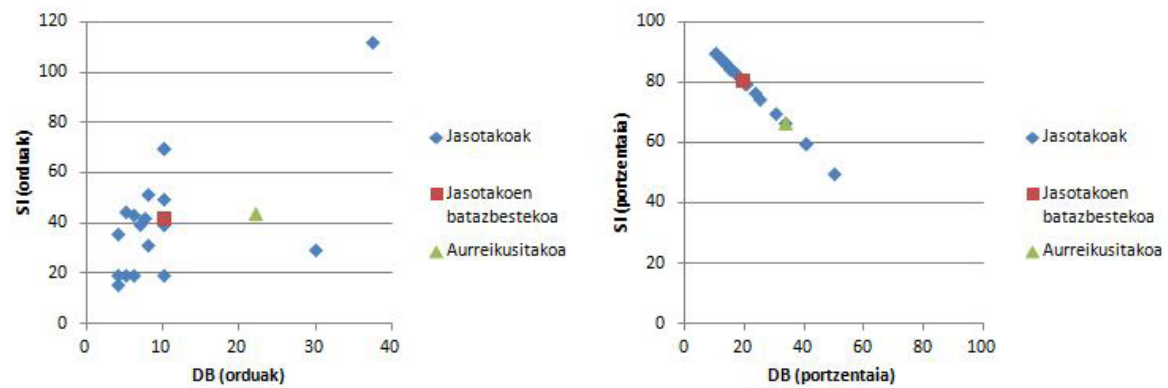

5. irudia. Orduen banaketa bi irakasgaien artean, balio absolutuetan eta portzentaietan.

Itxarotearen aldeko arrazoien artean batzuk aurreko galderan adierazitako onurak aipatzen dituzte. Beste batzuentzat proiektu amankomun batek egin beharreko lana errazten duela diote, beste irakasgaietarako denbora gehiago utziz. Esan bezala, kontuan izan behar da irakasgai bakoitza ikasturte ezberdinetan hartuz gero bi proiektu egin beharko lituzketela, bakoitza bere inplementazio eta datu-kudeaketarekin. Galdera honetan

\footnotetext{
3 3. atalean aipatu bezala garapen arloko beste irakasgairen bat gaindituta ez duten ikasleek batzuetan ez dira Software Ingeniaritza irakasgaian matrikulatzen.
} 
bereziki interesgarria iruditzen zaigu jadanik Datu-baseak gaindituta zuten ikasleen iritzia, aurreko urtean Datu-baseak irakasgaiko proiektua egin zutelako eta urte hartan proiektu amankomuna, eta haiek beste inork baino hobeto alderatu ditzaketelako bi aukerak. \% 87,5ek itxarotea gomendatzen zuten.

Gaztelaniako taldean, ordea, kontrako iritzia eman zuten ikasleek. Bakarrik \% 8,1a itxarotearen alde zegoen. Kontrako iritzia adierazi zutenek irakasgai bat atzeratzeak bere ikasketen amaiera datak izango lukeen eragin negatiboa adierazi zuten arrazoi nagusitzat. Ulergarria da zentzu honetan ikasleek adierazitako beldurra. Bi taldeen arteko emaitzak hain ezberdinak izanda, orain ikusita pena ematen digu euskarako taldean galdera hau proiektua hasi aurretik ere egin ez izanak.

Bestalde, euskarako taldean aldi berean bi irakasgaietan matrikulatuta zeuden ikasleei «Zure iritziz, ona izan da bi irakasgaien arteko koordinazioa?» galdera egin zitzaien. Galdetutako ikasleen artean, \% 85,7ek erantzun zion galderari, eta guztiak ados zeuden koordinazioa ona izan zela. Halere, zenbait ikaslek ondorengo hobekuntza proposatu zuten: kurtsoan zehar laborategi-saio amankomunen bat egitea bi irakasgaien artean, aldi berean irakasle guztiekin zalantzak argitzeko. Azkenik, proiektu amankomuna egin zuten ikasleei proiektuari eskaini zizkioten ordu kopuruari buruz galdetu zitzaien, bai orokorrean, baita irakasgai bakoitzaren zatiari zegokienez ere, eta gure estimazioekin alderatu genuen. Orduak estimatzeko Ingeniaritza Informatikoko irakaskuntzaren inguruan egindako hainbat ikerketatan oinarritu ginen. [11]ren arabera, ikasle bakoitzaren esfortzuaren estimazioak ez lituzke 20 ordu gainditu behar ECTS kreditu bakoitzeko. Gainera, kontu handia izan behar genuen proiektu handi honek kurtso bereko beste irakasgaietan albo-efektu negatiborik ez izateko [12]. Beraz, irakasgai bakoitzaren kreditu kopurua (sei), proiektuak irakasgai bakoitzaren azken notan duen pisua (\% 40 Software Ingeniaritza irakasgaian eta \% 20 Datu-baseak irakasgaian), eta proiektu bakarra ulertu, planifikatu eta kudeatu behar zela ${ }^{4}$ kontuan izanda, gure aurreikuspenen arabera ikasle bakoitzak proiektu osoari 66 ordu inguru eskaini behar zizkion (44 ordu Software Ingeniaritza irakasgaiaren zatiari eta 22 ordu Datu-baseak irakasgaiaren zatiari).

5. irudiko emaitzei erreparatuz, ikus daiteke Software Ingeniaritza irakasgaiaren kasuan aurreikusitako orduak berdintsuak izan zirela jasotakoen batezbestekoarekin (44 vs. 42 ordu), baina ez, ordea, Datu-baseak irakasgaiaren kasuan (22 vs. 10 ordu). Gure ustez, interpretazio-arazo bat izan

\footnotetext{
${ }^{4}$ Normalean ikasle bakoitzarentzat, irakasgai bakoitzeko proiektuaren esfortzuaren $\%$ 15a proiektua ulertu, planifikatu eta kudeatzeko estimatzen dugu. Proiektu amankomuna izanda irakasgai bakoitzean jarduera hauetako lana \% 10ra jaitsiko zela estimatu genuen.
} 
zen galdera honetan eta ikasleek inplementazioarekin zerikusia zuen esfortzu guztia Software Ingeniaritza irakasgaiaren ordu kopuruari esleitu zioten. Hau normala da, zaila baita bi zatien artean lerro zehatz bat ezartzea, bata noiz bukatu eta bestea noiz hasten den adierazten duena. Hau dela eta, esfortzuaren portzentaia bi irakasgaien artean nola banatu zen adierazten duen grafikoan ikus daiteke esfortzuaren \% 80,8 Software Ingeniaritzari eskaini ziotela eta \% 19,2, aldiz, Datu-baseak irakasgaiari, aurreikusitako $\% 66,7$ vs. $\% 33,3$ ren ordez.
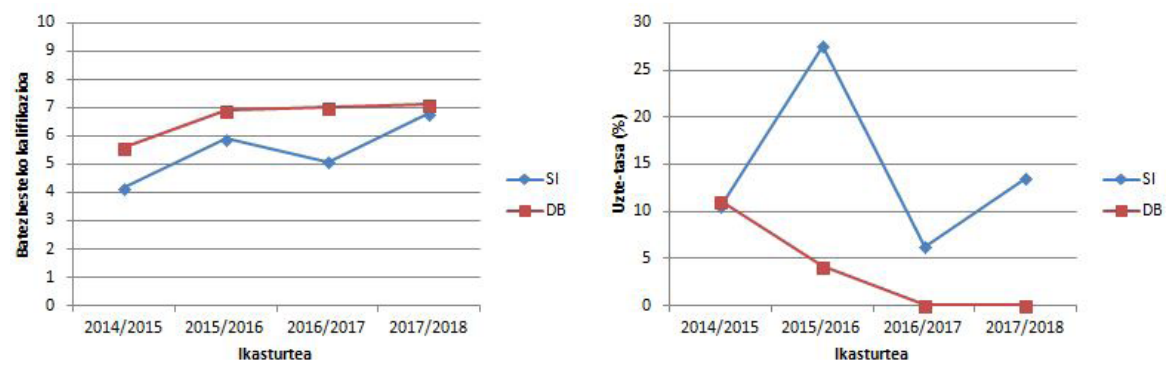

6. irudia. Azken notak eta uzte-tasa.

Halere, orduak beste era batera banatuta egongo balira ere, proiektu osoari eskainitako ordu totalak estimatutakoak baino gutxiago izan ziren (52 vs. 66 ordu). Esan beharra dago galdera honi erantzun zioten ikasleak orokorrean ikasle onak zirela. \% 92,7rentzat bere bigarren ikasturtea zen graduan, eta gainditze-tasa altua zen gure irakasgaiekin lotuta dauden hiru irakasgairekin (Oinarrizko Programazioa (\% 100ak gaindituta), Programazio Modularra eta Objektuetara Bideratutako Orientazioa (\% 92,7ak gainditua), Datu-egiturak eta Algoritmoak (\% 67,9ak gainditua, baina kontuan izanda hau ere bigarren mailakoa dela eta ez-ohiko deialdia ospatzear zegoela).

Inkestez gain, proiektu amankomuna egin zuten ikasleen azken notak eta uzte-tasa aztertu genituen. Aurreko urteetakoekin alderatuz (6. irudia) batezbesteko kalifikazioa igo zen bi irakasgaietan, batez ere Software Ingeniaritzaren kasuan. Uzte-tasari dagokionez ez da hobekuntza nabarmenik ikusten irakasgaietan.

\section{IKASITAKO LEZIOAK}

Edozein proiektu amaitu ondoren, hausnarketa bat egiteko garaia iristen da, gertatutakoa aztertu eta etorkizunerako baliagarriak izango diren ondorioak ateratzeko [13]. Gure kasuan, honako hauek dira proiektuan zehar 
ikasitako lezioak, antzeko ekimen bat aurrera eraman nahi duen irakasle talde bati interesgarriak izan dakizkiolakoan:

- Irakasleria. Ezinbestekoa iruditzen zaigu horrelako proiektu batean parte hartzen duen irakasleriak esperientzia izatea bai bere irakasgaiko edukietan eta baita irakasgai beraren irakaskuntzan ere. Horrelako zeharkako esperientzia batek bi irakasgaien arteko zubiak eraikitzea eskatzen du eta hori ezinezkoa da alde bakoitzeko oinarriak sendoak ez badira.

- Ikasleria. Gomendagarria iruditzen zaigu ikasleen gehiengoa bi irakasgaietan matrikulatuta egotea. Gure kasuan, 28 ikasle zeuden egoera horretan, bederatzi ikaslek Software Ingeniaritza bakarrik zuten eta sei ikasle Datu-baseak irakasgaian bakarrik zeuden. Baina irakasgaien profila dela eta, Software Ingenieritza bakarrik egiten ari zirenen artean denek zuten Datu-baseak irakasgaia gaindituta, eta, beraz, proiektua bere osotasunean egiteko gai ziren.

- Proiektua. Proiektuaren gaia aukeratzea ez da erraza. Bi irakasgaietako helburu pedagogikoak betetzeaz gain, ikasleak interesatu eta motibatu behar ditu. Gure kasuan hilabete inguru eman genuen aukera desberdinak eztabaidatzen Animalien Taberna aukeratu aurretik, baina erantzuna oso ona izan zen eta ikasleak eskola tarteetan animalia desberdinei buruz eztabaidatzen aurkitzen genituen. Honetaz gain, garrantzitsua da proiektu amankomuna egiten ez duten ikasleek ere proiektu interesgarri bat izatea, mugatuago gelditzen den arren.

Esan beharra dago gure kasuan Datu-baseak bakarrik zituzten ikasleen proiektuak arrakasta gutxiago izan zuela ikasleen artean, baina hurrengo ikasturterako Software Ingeniaritza irakasgairako motibatu zituelakoan gaude.

- Koordinazioa. Horrelako proiektu bat aurrera eramateko, ezinbestekoa da irakasleen arteko koordinazioa, proiektua baino lehen, proiektuan zehar eta proiektuaren ondoren. Proiektua baino lehen bi irakasgaien egutegiak lerrokatu behar dira, proiektua definitu, gai apropos bat aukeratu eta bi irakasgaietarako plangintzak prestatu. Proiektuaren garapenean zehar jarraipena eta kontrola egin eta proiektuaren bukaeran emaitzak aztertu eta ikasleen iritziak jaso hurrengo urteetarako. Gure kasuan uztailean hasi ginen proiektua definitzen eta gaia aukeratzen eta iraila eta abendua bitartean osatu genituen plangintzak eta proiektua definitu genuen irakaskuntza helburuen arabera. Fase honi aurre egiteko 36 bat ordu behar izan ziren. Esfortzuaren zehaztasunak 7. irudian ikus daitezke.

Proiektuaren iraupenean zehar, urtarrila eta maiatza bitartean, irakasleak astean behin bildu ginen jarraipena egiteko. Hau da, 45 ordu pasa ziren formalki koordinazioan fase honetan. Dena den, bilera 
programatu bat izan arren astero, aipatu beharra dago uneoro komunikazioa zegoela. Horrelako proiektu bat aurrera eramateko, garrantzitsua da irakasleen artean komunikazioa ona izatea, eta are gehiago esperientzia egiten den lehen aldian.

\begin{tabular}{|c|c|c|c|}
\hline \multicolumn{4}{|l|}{ Irakasleen esfortzua (ordutan) } \\
\hline Proiektuaren definizio eta plangintza & SI & DB & Guztira \\
\hline - Jokoaren aukeraketa ..... & 2 & $2 \times 2$ & 6 \\
\hline - Proiektuaren definizioa ... & 6 & $2 \times 2$ & 10 \\
\hline - Proiektuaren plangintza ... & 6 & $3 \times 2$ & 12 \\
\hline - Moldaketa DB bakarrik zuten ikasleentzat.. & - & $1 \times 2$ & 2 \\
\hline - Koordinazio bilerak (bi bilera) .................... & 2 & $2 \times 2$ & 6 \\
\hline Guztira & 16 & 20 & 36 \\
\hline Proiektuaren jarraipen eta kontrola & $\underline{\text { SI }}$ & $\underline{\mathrm{DB}}$ & Guztira \\
\hline \multirow[t]{2}{*}{ - Koordinazio bilerak (15 bilera, bat astean behin) } & 15 & $15 \times 2$ & 45 \\
\hline & 15 & 30 & 45 \\
\hline Proiektuaren hausnarketa & $\underline{\text { SI }}$ & $\underline{\mathrm{DB}}$ & Guztira \\
\hline - Inkestaren definizioa ............ & 2 & $2 \times 2$ & 6 \\
\hline - Iritzien bilketa (bi irakasgaietan, bi hizkuntzetan).. & 0,5 & 0,5 & 1 \\
\hline \multirow[t]{2}{*}{ - Emaitzen azterketa .. } & 2 & $2 \times 2$ & 6 \\
\hline & 4,5 & 8,5 & 13 \\
\hline Irakasleen esfortzu totala proiektuan: & & & 94 ordu \\
\hline
\end{tabular}

7. irudia. Irakasleen esfortzua fase eta jarduera bakoitzeko. Esan beharra dago Datu-baseak irakasgaian bi irakasle izan zirela, Software Ingeniaritzan irakasle bakarra aritu zen bitartean. Esfortzua hiru irakasleen batura da.

Bukatzeko, proiektu bukaeran ikasleen iritziak jaso genituen inkesta bidez eta emaitzak aztertu genituen. Fase honetan 13 ordu erabili ziren. Beraz, guztira, proiektu osoa aurrera eramateko 94 ordu behar izan genituen.

- Bestelakoak. Horrelako proiektu bat lehen aldiz aurrera eramatean, argi izan behar da gauzaren bat beti ahaztuko zaigula. Gure kasuan, Datu-baseak irakasgaian ikasleei datu-base bat nola esportatzen zen azaltzea ahaztu zitzaigun, ez baitzen irakasgaiaren parte. Horrek zuzenketak dexente zaildu zituen eta beste kurtso batean errepikatzen bazen aldatu beharko litzatekeen zerbait izango litzateke. 


\section{ONDORIOAK}

Esperientzia oso interesgarria izan zen irakasleontzat, eta, jaso ziren inkestak aztertu ondoren, esan dezakegu ikasleentzat ere horrela izan zela. Orokorrean ikasleek irakasgai bakoitza isolatuta ikusi ohi dute, bere gai eta ariketa edo praktikekin, eta ez dute irakasgai ezberdinen elkarloturarik ikusten Gradu Amaierako Lanera iristen diren arte. Honelako diziplina anitzeko proiektu batek irakasgaien arteko lotura hori ikusten laguntzen die.

Onurak garbiak diren arren, egoera ondo aztertu behar da horrelako proiektu batean murgildu aurretik. Oso garrantzitsua da irakasleek iragasgaiak menperatzea, ez edukiak bakarrik, baita irakasteko moduan ere. Horrek lagunduko du elkartzen diren irakasgaietako proiektuaren zati bakoitza ondo definitzen. Gainera, proiektuaren gaia erakargarria izatea gomendagarria da, horrek motibatuko baititu ikasleak.

\section{BIBLIOGRAFIA}

[1] BALCELLS, M. 2014. «El trabajo por proyectos: Una metodología global». Cuadernos de Pedagogía, 450, 7-13.

[2] RAILSBACK, J. 2002. «Project-based instruction: Creating excitement for learning». Portland, Oregon: Northwest Regional Educational Laboratory.

[3] GARCÍA-VARCÁLCEL, A. eta BASILOTTA, V. 2017. «Aprendizaje basado en proyectos (ABP): evaluación desde la perspectiva de alumnos de Educación Primaria». Revista de Investigación Educativa, 35(1), 113-131.

[4] LEÓN-DIAZ, O. eta MARTÍNEZ-MUNOZ, L.F. eta SANTOS-PASTOS, M.L. 2018. «Análisis de la investigación sobre Aprendizaje basado en Proyectos en Educación Física». Revista Electrónica Interuniversitaria de Formación del Profesorado, 21(2), 27-42.

[5] EUSKO JAURLARITZA. 2015. «Oinarrizko Hezkuntzako Curriculuma (236/2015eko Dekretuaren II. Eranskina osatzen duen curriculum orientatzailea)». https: //www.euskadi.eus/contenidos/informacion/heziberri_2020/ eu_2_proyec/adjuntos/OH_curriculum_osoa.pdf

[6] DEVESA, M.C. 2015. «Una experiencia de ABP en Primaria». https:// es.slideshare.net/mcarmendz/ una-experiencia-de-abp-en-primaria-55136996

[7] TOLEDO, P. eta SÁNCHEZ, J.M. 2018. «Aprendizaje basado en proyectos: una experiencia universitaria». Profesorado. Revista de Currículum y Formación de Profesorado, 22(2), 471-491.

[8] HERNANDEZ, A. eta LACUESTA, R. 2007. «Aplicación del aprendizaje basado en problemas (PBL) bajo un enfoque multidisciplinaruna experiencia práctica». Conocimiento, innovación y emprendedores: Camino al futuro. Universidad de La Rioja, La Rioja. ISBN: 84-690-3573-8. 
[9] VILLAGRÁ, C., GALLEGO, F. eta MOLINA, R. 2014. «ABPgame+: siete asignaturas, un proyecto». Actas de las XX Jornadas de Ensenanza Universitaria de Informática, JENUI 2014, ISBN: 978-84-697-0774-6, 285-292.

[10] AZNAR, F., PUJOL, M., SEMPERE, M. eta RIZO, R. 2012. «Adquisición de competencias mediante Aprendizaje Basado en Proyectos como metodología docente: valoración del alumnado». X Jornadas de Redes de Investigación en Docencia Universitaria.

[11] RIVADENEYRA, J.M. 2014. «Es realista planificar 25 horas por crédito ETCS?». ReVisión. Revista de Investigación en Docencia Universitaria de la Informática, 8(3).

[12] NAVARRO J., CANALETA X., VERNET D., COSTA N., SOLÉ, X. eta JIMÉNEZ, V. 2014. «Motivación, desmotivación, sobremotivación y danos colaterales». Actas de las XX Jornadas de Ensenanza Universitaria de Informática, JENUI 2014, ISBN: 978-84-697-0774-6, 467-474.

[13] PROJECT MANAGEMENT INSTITUTE. 2017. «La guía de los fundamentos para la direccón de proyectos (Guía del PMBOK)». Project Management Institute, Inc. 